\begin{abstract}
The eighteenth century was a period when ambitious Irish dramatists, particularly those based in London, deployed satire as a means of publicly displaying Irish improvement and Enlightenment. The Stage Irishman evolved over the period to become less an object than a tool of satire. Central to this process was new historiographical work by Irish historians that provided an ideological basis for this new drama. The Declaratory Act (1720) provoked Irish patriot writers; the failed Jacobite Rebellion (1745) offered them an opportunity to denigrate the Scottish to further Irish claims of Celtic authenticity; and the Irish rebellion (1798) muted the sense of possibility around the politics of national identity and satire.
\end{abstract}

\title{
National Identity and Satire
}

David O'Shaughnessy

That had we been an Unmix'd Nation, I am of Opinion it had been to Our Disadvantage: For to go no farther, we have three Nations about us as clear from Mixtures of Blood, as any in the World, and I know not which of them I could wish our selves to be like I mean the Scots the Welsh and the Irish.

Daniel Defoe, Preface to The Trueborn Englishman (1700-1)

Canker: Give us then a national portrait: a Scotchman or an Irishman

Foote: If you mean merely the dialect of the two countries, I can't think it either a subject of satyr or humour; it is an accidental unhappiness, for which a man is no more accountable, than the colour of his hair.

Samuel Foote, The Minor (1760).

Anxiety about immigration and concomitant fears of contagion were a persistent feature of British life throughout the eighteenth century. Commentators identified foreign manners, fashions, and fripperies as posing a collective threat of corruption to the idealized virtuous English character; they believed that workers were coming over to steal English jobs; and, they feared foreign incursions into conquered imperial geographies: such anxieties were an ever present feature of societal and critical discourse throughout our period. These anxieties stemmed from a variety of sources but looming large over the earlier part of the century were the uncomfortable facts that Britain had invited a Dutchman to take its crown and that it took until 1727 to crown a monarch who could actually speak English fluently (albeit still with a distinctly German accent). Religious concerns had taken precedence when it came to issuing William of Orange an invitation to take up the reins of power but residual unease with the shakiness of the claim that James II had abdicated persisted well into the century. The Williamite succession functioned as a proxy for the tensions - albeit often productive tensions - brought about by, as Howard Weinbrot has argued, the sustained 'broader mingling' of races and nationalities that occurred in eighteenthcentury Britain during the transition from 'the restoration of the Anglo-Norman 
French Stuart Charles II to the elevation of the Anglo-German British Hanoverian George III'. ${ }^{1}$

Daniel Defoe's feisty satirical riposte to those who saw William's accession as a regressive and polluting event made his literary name at the turn of the new century. Published in December 1700 or January 1701, The True-Born Englishman was a bestseller, enabling Defoe to make the transition from obscure pamphleteer to becoming the leading satirical poet of the day. ${ }^{2}$ A virulent anti-Catholic, Defoe was appalled by Whig writer John Tutchin and his verse assault on William, The Foreigners, which made much play of Dutch 'Vermin' who were 'Boorish, rude, and an inhumane Race' and other associated writings. ${ }^{3}$ Defoe's response to this print culture of xenophobia was a playful but caustic exposure of the nonsensical claims of his opponents' racial purity. His explanatory preface sets out his basic premise - 'That those Nations which are most mix'd, are the best, and have least of Barbarism and Brutality among them' (1.79) - but this measured view is expressed through railing attacks on Englishmen's degree of self-delusion when the country, conquered and invaded numerous times in its history is effectively 'Europe's sink, the Jakes where she / Voids all her Offal Outcast Progeny' (1.249-50), home to 'a Mongrel half-bred Race' (1. 340). Defoe's satire smacks more of a breezy jibe rather than an expression of enraged indignation, and all the more forceful for it. Appropriately, he employs a hybrid form with the fashionable heroic couplet amplified by the use of ballad refrain and all its folk resonance. Again and again, Defoe drives home Britain's long history of miscegenation:

Thus from a Mixture of all Kinds began, That Het'rogenous Thing, An Englishman:

In eager Rapes, and furious Lust begot, Betwixt a Painted Britton and a Scot (1.334-37)

Suvir Kaul has discussed how Defoe reverses the image of English colonial expansion by depicting the country as the 'virgin land raped by the violence of competing conquerors', showing us how the poem looks within as well as without Britain's borders. ${ }^{4}$ Defoe repeatedly calls attention to the palimpsestic genealogical layering that lies in England's past in his move to expose the hollowness of contemporary xenophobic ingratitude directed towards William. Kaul's observation that Defoe reverses the trope of imperial rapine provides us with a useful way in to thinking about satire and national identity within Britain over the course of this century of

This chapter has received funding from the European Union's 2020 research and innovation programme under the Marie Sklowdowska-Curie grant agreement No 745896.

${ }^{1}$ Howard Weinbrot, Britannia's Issue: The Rise of British Literature from Dryden to Ossian (Cambridge: Cambridge University Press, 1993), 2, 479.

${ }^{2}$ Defoe himself claimed that 21 editions had appeared by 1705,9 of them authorized. This success continued and it became the most frequently reprinted poem of the early eighteenth century with approximately 50 editions appearing before 1750 .

${ }^{3}$ The True-Born Englishman and other Poems, ed. W.R. Owens, vol 1 of Satire, Fantasy and Writings on the Supernatural by Daniel Defoe, 8 vols (London: Pickering \& Chatto, 2003), 17-18.

${ }^{4}$ Suvir Kaul, Poems of Nation, Anthems of Empire: English Verse in the Long eighteenth Century (Charlottesville and London: University of Virginia Press, 2000), 88 . 
imperial expansion. Defoe forcefully reminds his readers that Britain is and always has been a site of contestation, a reality that cannot be cloaked by any mythologizing about racial coherence. As Joseph Addison would suggest, London's cosmopolitanism was largely a benign phenomenon that helped confirm Britain's sense of commercial and moral superiority as well as shoring up its Enlightenment credentials:

There is no Place in the Town which I so much love to frequent as the Royal-Exchange. It gives me a secret Satisfaction, and, in some measure, gratifies my Vanity, as I am an Englishman, to see so rich an Assembly of Country-men and Foreigners consulting together upon the private Business of Mankind, and making this Metropolis a kind of Emporium for the whole Earth. ${ }^{5}$

London's many theatres were also sites where rich assemblies of English and other nationalities would consult together upon the business - both public and private - of mankind. This essay will look primarily at dramatic satire on the London stage as it relates to Irish national identity. In focusing on theatre, it will provide some small redress of the problem noted recently by Ashley Marshall of the traditional tendency to privilege verse satire over that of plays or novels and in tune with reinvigorated work on eighteenth-century theatre. ${ }^{6}$ Why the particular emphasis on the Irish case? It is certainly true that other national or ethnic identities could prove fruitful. During the 'Second Hundred Years War', British writers were not shy of attacking the French.' The Dutch and Germans also featured regularly while anxieties about Jewish residents also emerged in numerous satirical stage depictions, particularly in the $1780 \mathrm{~s} .^{8}$ But it is the Irish theatrical diaspora - of all peoples migrating to Britain in the eighteenth century - that was by far the most populous and successful and this qualifies it for particular attention. ${ }^{9}$ Moreover, while there were certainly satiric dramatizations of

\footnotetext{
${ }^{5}$ Erin Mackie (ed), The Commerce of Everyday Life: Selections from The Tatler and The Spectator (Boston: Bedford/St Martin's Press, 1988), 203.

${ }^{6}$ See, for example, recent special issues on theatre from Eighteenth-Century Fiction $(27: 3 ; 2015)$ and Eighteenth-Century Studies $(48: 4 ; 2015)$ and Julia Swindell and David Francis Taylor (ed), The Oxford Handbook to Georgian Theatre, 1737-1832 (Oxford: Oxford University Press, 2014).

${ }^{7}$ Examples are rife throughout our period and include George Alexander Stevens's The French Flogged (1760), the anonymously authored The Conquest of St Eustacia (1781), and, as noted by Bate, the pointed performances of Henry V in the 1790s. Jonathan Bate, Shakespearean Constitutions: Politics, Theatre, Criticism, 1830-1830 (Oxford: Clarendon Press, 1989).

${ }^{8}$ Moses and Shadrac; or, A Specimen of Jewish Education (1780), John O'Keeffe, The Young Quaker (1783), The Fair Refugee; or, The Rival Jews (1784), and A Specimen of Jewish Courtship (1787). We should also note sympathetic portrayals of the Jewish character in Richard Brinsley Sheridan's The School for Scandal (1777) and Tobias Smollett's sympathetic portrayal of the Jewish character in his The Israelites; or, The Pamper'd Nabob (1785).

${ }^{9}$ This can be demonstrated by a qualitative roll-call of major Irish dramatists, actors, and theatre managers of whom Farquhar, Goldsmith, Sheridan, Woffington and Clive are just a few. The quantitatively-inclined can see the extent of the Irish dominance by doing comparative searches in the $O D N B$ for theatrical personages by Celtic nation of
} 
the Scots and, to a lesser extent, the Welsh, the 'Stage Irishman' was an integral part of the comic genre. ${ }^{10}$ Therefore, the Irish offer a particularly rich opportunity to think about the relationship between satire and national identity: they were regular targets of the mode as well as producing some of its leading proponents.

As the essay works its way through the century, I want to consider London as a site of contestation for this aspirational diasporic grouping for whom satire of national identity was initially a barrier - or representative of a barrier- to acceptance, integration and social mobility. However, as the century progresses, there is increasing evidence that the practice of satire is understood as a means to demonstrate cultural capital and it becomes a proxy for increasing collective confidence and tolerance. By appropriating and redirecting the invective of satire, the Irish were able to reverse - to some degree at least - long held stereotypes of ignorance and barbarity. Moreover, it might be argued that this movement is enabled through developments in historiography over the period, also a discursive site of much contestation. Aligning satire, drama, and historiography, I want to show how satire here might be understood as a strain of Irish Enlightenment where it is less a means of 'Reformation', as Defoe would have had it, but rather, as Dustin Griffin has laid out, a method of inquiry and provocation, and ultimately, a means for the public display of improvement. ${ }^{11}$ In a double move, perhaps diminishing its Enlightenment pretensions, satire can expose the failings of the satirized while displaying the sophisticated literary aplomb of the satirist, exposing the cultural gulf between different nations in a contest of public opinion that appears to have been perceived by some as a zero-sum game. Notwithstanding Addison's beaming self-congratulatory sense of London being the natural home of citizens of the world, the cosy camaraderie he describes occludes the competition between these commercial agents, often drawn along national lines, which spread into the realm of culture, particularly for the Irish and Scots. ${ }^{12}$ Between these two Celtic tribes, 'almost the same but not quite', 1745 was the date which proved particularly significant. For it allowed the Irish to put the events of 1641, a date which cast a long shadow over the seventeenth and eighteenthcentury Irish, to rest. For those who chose to migrate to England, the historical accounts of the Ulster rebellion were a significant obstacle.

birth (a reasonable proxy for nationality): the score, for persons active 1700-1800 in the sphere of 'Theatre and live Entertainment', reads Ireland 66; Scotland 13; and Wales 4.

${ }^{10}$ G. C. Duggan, The Stage Irishman (Dublin: Talbot Press, 1937); J. O. Bartley, Teague, Shenkin, and Sawney (Cork: Cork University Press, 1954); Joep Leerssen, Mere Irish and Fior Ghael: Studies in the Idea of Irish Nationality, its Development and Literary Expression Prior to the Nineteenth Century (Cork: Cork University Press and Field Day, 1986); and, David Hayton, 'From Barbarian to Burlesque: English Images of the Irish c. 1660-1750', Irish Economic and Social History 15 (1988), 5-31.

${ }^{11}$ Dustin Griffin, Satire: A Critical Reintroduction (Lexington, KY: University of Kentucky Press, 1994).

${ }^{12}$ See "London's Irish Merchant Community and North Atlantic Commerce in the Mid-Eighteenth Century," in Irish and Scottish Mercantile Networks in Europe and Overseas in the Seventeenth and Eighteenth Centuries, David Dickson, Jan Parmentier, and Jane Ohlmeyer, eds. (Ghent: Academia Press, 2007). 
John Temple's History of the Irish Rebellion (1646) was unequivocally vituperative in its assessment of Irish Catholic brutality in the 1641 rebellion: the full title refers to 'the barbarous cruelties and bloody massacres which ensued thereupon' leaving the reader in little doubt as to which way Temple's lurid account was going to play out. Temple's take on the events, as Joep Leerssen has documented, revivified and concretized ideas of Irish savagery which had been extant since Strabo. ${ }^{13}$ Other events helped keep Temple's text in the public consciousness. After Titus Oates's mendacity during the Popish Plot of 1678-1681, Temple's history was reprinted, as it was again in subsequent times of political stress (for example, 1698, 1716, and 1746). The cumulative effect of these events and the historical writing they provoked had significant cultural effects, particularly in terms of the dramatic repertoire. Yet, as noted by David Hayton, satirical depictions of the Stage Irish were often broad humoured and, after the defeats of James II in 1690 and 1691, the English dread of the 'wild Irish', often along racial grounds, was replaced by more of a contemptuous sneer. ${ }^{14}$ The ostensible military prowess of the Irish Catholics - which prompted panic in December 1688 when Irish troops were thought to be rampaging through the south of England - no longer seemed possible in the wake of the battles of the Boyne and Aughrim. Contempt is a far easier emotion to fuse with humour, particularly satire, than fear and hence we have a proliferation of satires across a variety of genres that poke fun with varying degrees of hostility at the Irish. ${ }^{15}$

Thus, it is a given that eighteenth-century print and oral culture frequently saw the Irish and Ireland as an object of satire. There have been many treatments of this phenomenon, particularly around the stage, and this essay will not seek to add to these. ${ }^{16}$ The Irish were particularly prone to the 'weak multiculturalism' of eighteenth-century Britain where early fear never quite dissipated entirely, although it did dilute to a disdainful and sniffy tolerance in the mid-century before hardening again after $1798 .{ }^{17}$ However, following recent more benign readings of the opportunities identified and exploited by the Irish in eighteenth-century Britain, this essay will look at the Irish who used satire as a means of publically demonstrating Enlightenment ideas of improvement, politeness, civility, and combative intellectual exchange to a sceptical audience. ${ }^{18}$ This satiric practice is linked to historiography and

${ }^{13}$ Leerssen, Mere Irish and Fior Ghael, 58-60.

${ }^{14}$ Hayton, 'From Barbarian to Burlesque'.

15 'Lilliburlero', which features in Tristram Shandy, is the best known song. On plays from c.1690, see Bartley, Teague, Shenkin and Sawney, 106-9 and Leerssen, Mere Irish, 97-102. Two prominent early Irish jokebooks are Bog Witticisms; or, Dear Joy's Common-Places (1682) and Teagueland Jests, or Bogg-Witticisms (1690); see Helen Burke, 'The Irish Joke, Migrant Networks, and the London Irish in the 1680s', Eighteenth-Century Life 39:1 (2015), 41-65.

${ }^{16}$ Cf. n. 9 above.

${ }^{17}$ See Helen Burke, "'Integrated as Outsiders": Teague's Blanket and the Irish Immigrant "Problem" in Early Modern Britain', Éire-Ireland 46:1\&2 (2011), 20-42, 25.

${ }^{18}$ See Craig Bailey, Irish London: Middle-class Migration in the Global Eighteenth Century (Liverpool: Liverpool University Press, 2013); Networks of Aspiration: The London Irish in the long eighteenth century, special issue of Eighteenth-Century Life, 39:1 (2015), 1-235. Also relevant to this positive narrative of eighteenth-century Irish 
landmark publications of historical texts. It provided satirists, particularly playwrights, with the necessary confidence and ethnographic 'evidence' for the reimagining of the Irish national character. Noelle Gallagher has reminded us of the close links between satire and historical writings, both understood in the early eighteenth century as sharing formal and thematic features. They both had classical antecedents, concerned themselves often with the actions of 'great men', often had didactic objectives, interested themselves in public matters, reached broader audiences than perhaps intended, and were politically engaged. ${ }^{19}$ In the competitive space of London, as the Irish and Scots grappled for supremacy, satires were 'frequently and self-consciously mobilized as vehicles for historical representation' ${ }^{20}$ Moreover, significant historical publications influenced the tone of satire produced by key Irish writers: as the Irish proved themselves capable of participating in the Enlightenment discourse of historiography, satire was emboldened and its vitriol diluted. At the same time, the Enlightenment credentials of such works were always under pressure as historiographic and cultural clashes with the Scots occurred regularly: pretensions of Enlightenment could be undermined by sheer rudeness. ${ }^{21}$

Yet before we travel to London, it would seem more than rude to pass over Jonathan Swift in an essay on satire and national identity. Swift's importance is twofold: not only is he recognized as one of the most important satirists of the century, his afterlife and influence over subsequent generations of eighteenth-century Irish writers, particularly those of a patriot bent, is crucial. ${ }^{22}$ Two texts in particular help us establish the case for considering satire of national identity alongside historiography, The Story of the Injured Lady (1707) and A Modest Proposal (1729). ${ }^{23}$

In the Injured Lady, his early satirical allegory, Swift lays out a litany of Irish complaints related to the union of 1707 before a conclusion which, following on from William Molyneux's A Case for Ireland (1699), highlights the problem of corrupted historical memory. England, Swift complains, has torn up the 'old Compact' between England and Ireland in which they agreed to have 'the same Steward' which would allow Ireland to 'regulate [its] Family and Estate by the same Method' as England. The injured lady claims that this compact was 'writ down in Form' but that 'the Turn he thinketh to give this Compact of ours is very extraordinary' since it is being ridden over roughshod by the lover. Of course, there was no formal constitutional settlement which laid out how England would govern Ireland, the closest document to this was Poynings's Law (1495). The 'compact' alluded to might well be this act or might

improvement is Michael Brown's The Irish Enlightenment (Cambridge, Mass: Harvard University Press, 2016).

${ }^{19}$ Noelle Gallagher, Historical Literatures: Writing about the Past in England 16601740 (Manchester University Press, 2012), 114-16

${ }^{20}$ Ibid., 159.

${ }^{21}$ On the idea of a 'rude' Enlightenment, see Michael Brown, 'The Biter Bitten: Ireland and the Rude Enlightenment', Eighteenth-Century Studies 45:3 (2015), 393 407.

${ }^{22}$ See Robert Mahony, Jonathan Swift: The Irish Identity (New Haven \& London: Yale University Press, 1995).

${ }^{23}$ For a recent account of Swift's engagement with history and historiography, see Ashley Marshall, Swift and History: Politics and the Past (Cambridge: Cambridge University Press, 2015). 
simply be synecdochal of the litany of English legislative measures related to Ireland: whatever it may be, Swift calls attention to the problems inherent in corrupted historical memory and thus to the importance of correct historical accounts to guide politically just behaviour. A true account of the injured lady's character, a history told with 'Modesty and Truth', on the other hand, is a tale of 'Grief and ill Usage'; born to a 'good Estate' the years have brought nothing but oppression and sorrow. In a marvelous twist of one of the standard satirical tropes by which the Irish were represented - one that would persist through the century - Swift reverses the trope of the rakish Irish fortune-hunter and suggests that a true historical account shows just the opposite:

Some Years ago, this Gentleman, taking a Fancy either to my Person or Fortune, made his addresses to me; which, being then young and foolish, I too readily admitted [...] I was undone by the common Arts practiced upon all easy credulous Virgins, half by Force, and half by Consent, after solemn Vows and Protestations of Marriage.

In what might be seen as an associated move, he also redirects the gaze of the English reader, long accustomed to bestial descriptions of the Irish physiognomy. His caustic gaze dismisses the corporeal charms of the new preferred mistress of England:

tall and lean, and very ill-shape; she hath bad Features, and a worse Complexion; she hath a stinking Breath, and twenty ill Smells about her besides; which are yet more unsufferable by her natural Sluttishness; for she is always Lousy, and never without the Itch. ${ }^{24}$

Swift's first Irish pamphlet, written in the slipstream of Anglo-Scottish union and Molyneux's Irish patriot urtext, is a jolting satirical broadside aimed at correcting the historical record and putting English mismanagement firmly into focus. It does so not only by an acerbic reimagining of the relationship but by appropriating tropes and strategies often used to dismiss the Irish as unworthy of political autonomy on the individual and collective level.

If the Injured Lady shows us Swift's capacity for visceral and grotesque imagery to make a political point, his most famous Irish satire, written some twenty years later, A Modest Proposal (1729) surpasses it in terms of heightened invective. This bold attack on British economic policy towards its Hibernian neighbor is simultaneously appalled by and appalled at the Irish Catholic condition. This infamous pamphlet outrageously suggests that Irish Catholic children be harvested to feed the country's populace in a breathtaking satire that not only confronts Britain but more generally, undermines Enlightenment trends for improving projects as well as their fetishizing of rationality, measurement, and quantification. Swift also deals with the question of history writing: in the Modest Proposal he pokes fun at the outrageous claims made about Irish Catholics while perhaps suggesting that historiography, properly conceived, can be an important tool for national self-assertion. $\mathrm{He}$ makes a brief but important explicit connection between satire and history:

${ }^{24}$ Joseph McMinn (ed), Swift's Irish Pamphlets: An Introductory Selection (Gerrard's Cross: Colin Smythe, 1991), 23, 24, 27. 
But in order to justify my Friend: he confessed, that this Expedient was put into his Head by the famous Salmanaazor, a Native of the Island Formosa, who came from thence to London, above twenty Years ago, and in Conversation told my Friend, that in his Country, when any young person happened to be put to Death, the Executioner sold the Carcase to Persons of Quality, as a prime Dainty; and that, in his Time, the Body of a plump Girl of fifteen, who was crucified for an Attempt to poison the Emperor, was sold to his Imperial Majesty's prime Minister of State, and other great Mandarines of the Court, in Joints from the Gibbet, at Four Hundred Crowns. ${ }^{25}$

To unpack the significance of this strand of the pamphlet, we must be aware that cannibalism was a habit attributed to the Irish by ancient and medieval historians. ${ }^{26}$ Along with incest, bestiality, and a propensity of savage violence such traits were collective evidence of barbarity and ample justification for a colonial regime. George Psalmanazar was a notorious imposter whose $A n$ Historical and Geographical Description of Formosa (1704-1705) had been exposed shortly afterwards as a fraud. The preface added to the second edition claimed, by way of authenticity, 'he must be a Man of prodigious parts, who can invent the Description of a Country, contrive a Religion, frame Laws and Customs, make a Language, and Letters \&c'. ${ }^{27}$ This must have brought a wry smile to the face of the recent author of Gulliver's Travels but it also signaled to the alert reader the connections between historiography and grotesque calumnies on national identity. The satire is polyvalent, a reprimand to the reader who might have been duped at an earlier point in the pamphlet as well as a barb directed at London celebrity publishing fads earlier in the century. The nod to Psalmanazar in A Modest Proposal indicates that ideas of national identity as mediated through 'history' need to be carefully scrutinized and there was a particularly Irish context for this necessity. Swift was aware of recent historiographical attempts at revisionism with regard to the representation of the Irish. He owned a copy of William Nicolson's The Irish Historical Library (1724), a Protestant endorsement of positive Irish representations and one which debunked what writers such as Strabo had to say as 'imperfect Scraps of Tales, of the barbarous Customs and Manners of the old Irish, brought to them from afar; and they drew up the Representation, at full length, in a more ugly and frightful dress' ${ }^{28}$ Moreover, he was a close friend of Dr Anthony Raymond, noted antiquary, who was engaged in a project to translate Geoffrey Keating's Foras Feasa na hEirinn, a strident riposte to centuries of prejudicial accounts of the Irish nation. Keating's indignant preface complains that for centuries British chroniclers of Ireland, 'seem to imitate the Beetle, which [...] passes over the delightful Fields, neglectful of sweet Blossoms, or fragrant Flowers that are in

\footnotetext{
25 Ibid., 147.

${ }^{26}$ Leerssen, 32, 39.

${ }^{27}$ An Historical and Geographical Description of Formosa, $2^{\text {nd }}$ edition (London: Mat. Wotonn et al, 1705), second preface, np.

${ }^{28}$ William Nicolson, The Irish Historical Library. Pointing at most of the Authors and Records in Print or Manuscript, Which may be serviceable to the Compilers of a General History of Ireland (Dublin: W. Taylor, 1724), 1-2.
} 
its way till [...] it settles itself on some nauseous Excrement' ${ }^{29}$ He continues by listing examples of national traits that have been unfairly transposed onto the Irish character - such as cannibalism, violence, sexual licentiousness - to give the impression of a savage race entirely lacking in culture. Keating's outraged rejection of accounts of Irish cannibalism may have filtered through Swift's mind as he wrote $A$ Modest Proposal: Swift was well aware of Raymond's work and ambition and thus it is possible that the reference to Psalmanazar, and a scandal by then well over a decade old, may have been connected with Swift's acquaintance with dubious histories through Raymond. ${ }^{30}$

Raymond never published his translation of Keating. Dermod O'Connor worked for him for a while, assisting with the translation, but eventually - much to Raymond's ire - went to London and published his own translation. ${ }^{31}$ The General History of Ireland was published by subscription in $1723 .^{32}$ The publication of Keating's abrasive narrative in a London translation (perhaps assisted by John Toland) in the wake of the 1720 Declaratory Act signals a more assertive Irish cultural formation in the English capital, one that attracted significant subscribers and readers (subsequent editions were published in 1726, 1732, and 1738). ${ }^{33}$ The well-heeled and varied subscriber list, headed by King George and populated by prominent aristocrats, lawyers, soldiers, merchants, archbishops, booksellers, and educators, indicates a growing tolerance for such historical revisionism. Moreover, we also note some names on the list that have particular resonance for Irish patriotism in the eighteenth-century - such as Molyneux, Philpot, and O'Conor - that illustrate the links between patriot sentiment and revisionist history.

If historical writings were once the means of impugning the Irish character, later writers understood that harnessing the symbiotic force of history and drama was also the means of redressing it. Keating wrote his history with a specific political purpose of reclaiming Irish history for the Irish and in a way that would unite both the Gaelic Irish with the Old English (i.e. early English Catholic settlers). If history was understood by Keating in the seventeenth century as providing the bedrock for reconciliation and national unity, theatre was a potent cultural forum to build on this groundwork, particularly for writers based in London in the eighteenth century. Such possibilities were heightened by the

${ }^{29}$ Geoffrey Keating, The General History of Ireland, trans. Dermod O'Connor (London: B. Creake, 1723), i. These words are echoed by Raymond in his A Short Preliminary Discourse to the History of Ireland (London: np, 1725), a pamphlet published in London to promote his planned work and read by Swift.

${ }^{30}$ For Swift's friendship with Raymond, see Andrew Carpenter and Alan Harrison, 'Swift, Raymond and a Legacy', Swift Studies 1 (1986), 57-60.

${ }^{31}$ Diarmuid Ó'Cathàin, 'Dermot O'Connor, Translator of Keating', EighteenthCentury Ireland 2 (1987), 67-87.

${ }^{32}$ Bernadette Cunningham, The World of Geoffrey Keating: History, Myth and Religion in Seventeenth-Century Ireland (Dublin: Four Courts, 2000).

${ }^{33}$ Keating's history also influenced Sarah Butler's Irish Tales (1716). Also published in London, this early novel is striking for its Jacobite sympathies and confident espousal of Irish culture. 
tumultuous effects of the failed 1745 Jacobite Rebellion which presented an opportunity that was eagerly grasped by this group.

When Scottish troops made it to within 130 miles of London in the autumn of 1745, it was not doom and gloom for all aspects of metropolitan life. 'The Rebellion', as Susannah Cibber wrote to Garrick that September, 'is so far from being a disadvantage to the playhouses that, I assure you, it brings them very good houses' ${ }^{34}$ Cibber was referring to her father-in-law's play The Non-Juror (1717), a reworking of Moliere's Tartuffe, whose depiction of the fiendish Scot Dr. Wolf was grist to the mill of contemporary patriotic fervor. Anti-Scottish sentiment was rife but Scotland's difficulty was also Ireland's opportunity as Charles Macklin, of whom more below, was quick to spot. ${ }^{35}$ The rebellion offered Irish writers like Macklin a chance to put the case for Irish civility to English audiences now more perturbed by northern Britons. ${ }^{36}$ Charles O'Conor, the major figure of Irish Catholic Enlightenment of the eighteenth century, is an important enabling figure here. To press the case for civil rights and the repeal of the penal laws, O'Conor understood a shift in the British attitude to Irish culture and history needed to be effected. ${ }^{37}$ To that end, he authored Dissertations on the Ancient History of Ireland (1748) which acknowledged the influence of Keating while at the same time distancing itself from the fantastical elements of that earlier work. O'Conor was keen to present his work - and by extension, Irish cultural history as a whole - as a model of Enlightenment methodology and civility. Critically, he understood absolutely that London was central to the progression of Irish claims for civil rights. In 1757 he wrote to Swift's publisher, George Faulkner, recently returned to Dublin:

${ }^{34}$ Cited in The London Stage 1660-1800: A Calendar of Plays Part III, ed. Arthur H. Scouten (Carbondale: Southern Illinois Press, 1861), II: 1187.

${ }^{35}$ A veteran actor of some twenty years Macklin capitalized on the prevailing mood and penned a historical tragedy titled King Henry VII, or, The Popish Impostor which retold the story of Perkin Warbeck, the fifteenth-century Pretender. Staged first on 18 January 1746, the play's prologue made Macklin's political position clear in case anyone might be in doubt about his loyalties:

When Popish Rage, \& Persecution blaz'd

And Britons bled on Altars Rome had rais'd;

When Matrons saw their Sons in Flames expire

And Husbands crackling in religious Fire,

Then Rome gave laws; our Kings \& Council sway'd

While Briton mourn'd her Liberties betray'd.

But now she smiles, the Laws are all her own,

And rule alike the Cottage \& the Throne.

${ }^{36}$ It is entirely apposite that Swift's The Story of the Injured Lady, although written c. 1707 was only published in 1746 .

${ }^{37}$ For a recent assessment of O'Conor, see Luke Gibbons and Kieran O'Conor (ed), Charles O'Conor of Ballinagare, 1710-91 (Dublin: Four Courts, 2015). 
I heartily congratulate with you, dear sir, on your safe arrival in a country to which you have rendered more service than any other public or private writer for several years past. The hints you give and the truths you press are, I think, preferable to essays which fall but into few hands and become profitable in fewer. It was an observation of our patriot Dean (your particular friend) that plans of reformation from without doors were seldom considered within. ${ }^{38}$

O'Conor's wry wordplay suggests that the very fact of mixing in London's public sphere as having the potential force of parliamentary discussion, at least when compared to trying to effect political change from Ireland. The 'within' of London public opinion was critical to the advance of the Irish Catholic cause. O'Conor knew this and was using Faulkner to ask Samuel Johnson to write pamphlets for the Irish cause. There is no evidence that Johnson complied but he was certainly sympathetic to O'Conor's aspirations. He wrote to him on 9 April 1757 regarding his recent meeting with Faulkner:

I have long wished that the Irish Literature were cultivated. Ireland is known by tradition to have been once the seat of piety, and learning; and surely it would be very acceptable to all those who are curious either in the original of nations, or the affinities of Languages, to be further informed of the revolutions of a people so ancient, and once so illustrious. ${ }^{39}$

O'Conor's correspondence also reveals the extent to which he was obsessed by David Hume's graphic depiction of 1641 Irish Catholic violence in his History of England, a bugbear he must have thought the Irish had consigned to the bin of history:

In the picture, for instance, which you give of Ireland, no comely features appear: the deformity of some is exaggerated extremely; others are monstrous, and have nothing like them in the original. Your failure can be easily accounted for: you took your copy from the draughts of others; from men who deemed the suppression of truth as necessary to keep their adversaries from rising, as they found the suppression of justice necessary to pull them down. ${ }^{40}$

O'Conor's Scottish enmity was compounded by James MacPherson's Temora (1763) in which the author laid claim to Scotland being the true 'original' Celtic nation. O'Conor's rebuttal took the form of a revised version of the

${ }^{38}$ O'Conor to Faulkner, 4 May 1757. The Letters of Charles O'Conor of Balangare, 2 vols, ed. Catherine Coogan War and Robert E. Ward (Ann Arbor, Michigan: Irish American Cultural Institute, 1980), 1: 32.

${ }^{39}$ Johnson followed up in May 1777 with a similar letter of encouragement. The Letters of Samuel Johnson, ed. Bruce Redford, 3 vols (Oxford: Clarendon Press, 1992), 1:152, III:23-24.

${ }^{40}$ The Gentleman's Museum, 1 (April 1763), 56. The writing and re-writing of this letter was the subject of a number of letters by O'Conor to John Curry in August and September 1762. See Letters of Charles O'Conor, 1: 138-42. 
Dissertations on the History of Ireland (1766) which included an extended coda exploding MacPherson's claims. While writing this work, he also made interventions into the London newspapers which were becoming increasingly important to the eighteenth-century public sphere. In one dated August 1763, he echoed the patriot Dean, contrasting English treatment of the Irish and the Scots and by not being afraid to ramp up the fears of Scottish violence by reminding readers of the rebellions of 1708,1715 , and 1745 and contrasting them to the 'quiet and dutiful' behavior of Irish Catholics which was 'perfectly blameless in every respect'. ${ }^{41} \mathrm{O}$ 'Conor was a wily political observer and his scaremongering about Scottish self-interested invaders along with plentiful appeals to English 'liberty' had a particular resonance in 1763 and offered Irish activists such as himself an opportunity to align themselves with an indignant English populace.

O'Conor's letter to Hume appeared in the first number of the Gentleman's Museum, a short-lived periodical. Nonetheless, the table of contents for this nondescript publication shows the degree to which issues of national identity were to the fore at this moment as there were items relating to The North Briton and the new cider tax, both issues of significant import for the current First Lord of the Treasury, Lord Bute, whose period in office ended in ignominy, also in April 1763, after only eleven months. The Treaty of Paris, which settled the Seven Years' War, was finalized in November 1762 and was the death-knell of his political career. Although modern historians hold that the treaty was in fact advantageous to Britain, political opponents were quick to pounce on its perceived shortcomings and link them to Bute's Caledonian roots and his corrupt desire to advance his countrymen's welfare at the expense of the nation. The abuse that Bute received while he was in office and indeed afterwards was scabrous. ${ }^{42}$ Chief among those critics were John Wilkes, Charles Churchill, and Charles Macklin.

When Bute took office in May 1762, he initiated a political weekly, The Briton, to defend his administration, edited by fellow Scot Tobias Smollett. ${ }^{43}$ One month later, Wilkes established the North Briton, an anti-ministerial weekly whose weekly sales were nearly $2000 .{ }^{44}$ Its tone was scurrilous as Horace Walpole commented: 'The North Briton proceeded with an acrimony, a spirit, and a licentiousness unheard of before even in this country. The highest names whether of statesmen or magistrates, were printed at length and the insinuations went still higher'. ${ }^{45}$ Still, Wilkes escaped prosecution until the infamous Number 45, published 23 April 1763. The story of this seditious libel is well known and need not be rehearsed here. Our interest is in one of the better

\footnotetext{
${ }^{41}$ London Chronicle, 27-30 August 1763. See also O'Conor to John Curry, [15 September 1763]. Letters of Charles O'Conor, 157.

42 John Brewer, 'The Misfortunes of Lord Bute: a Case-Study in Eighteenth-Century Political Argument and Public Opinion', Historical Journal 16 (1973): 3-43.

${ }^{43}$ The Briton was later supported by Arthur Murphy's Auditor, showing that the Irish and the Scots were not always opposed and national identity would not always trump personal advancement, emolument, or party political sentiment.

${ }^{44}$ John Wilkes: A Friend to Liberty, 20.

${ }^{45}$ Ibid., 21.
} 
known associated verse publications written by Wilkes's great friend, Charles Churchill, also a caustic critic of Bute's policies.

The Prophecy of Famine. A Scots Pastoral was published in January 1763 and dedicated to Wilkes. The poem was quickly recognized as one of the most potent and witty attacks on the Bute administration, with a neat conflation of Bute and James II 'STUARTS without end' (115) and a reminder of various Scottish antagonisms on the English, not least of which was the ransoming of Charles I ['Shall we not find, safe in that hallow'd ground, / Such refuge, as the HOLY MARTYR found' (121-22)]. Various other examples of Scottish degeneracy can be found including, in an interesting overlap with O'Conor, an attack on MacPherson's Ossian poems with the sneering line 'That old, new Epic Pastoral, FINGAL' (130). The insinuation being that in Bute's London, MacPherson's hotch-potch of muddled generic miscegenation can, 'take, with simple pensions, simple praise' (139). One might also read in these lines the expression of English sympathy to the Irish cultural agenda.

Around the same time as Churchill was writing, Macklin, an ardent Wilkesite, decided to get in on the act. Perhaps still feeling some vestigial irritation at Smollett's public jeering of him in Roderick Random (1748) with regard to the failure of Henry VII, he saw an opportunity to align himself with popular metropolitan English sentiment and he turned to writing satirical comedy. ${ }^{46}$ Macklin had already had considerable success with his two-act farce Love á la Mode (1759) in which he reworked the suitor scene from The Merchant of Venice. In Macklin's version, Charlotte, the wealthy heiress of Sir Theodore Goodchild, is courted by four distinctive types: Mr Mordecai, Squire Groom, Sir Archy Macsarcasm, and Sir Callaghan O'Brallaghan. The Jew, the Englishman, the Scotsman, and the Irishman squabble over the destination of Charlotte's heart (and dowry) with national traits being central to the play's interests. Sir Archy and Sir Callaghan are the central antagonists with the former determined to ensure the latter reveals himself as a blundering and violent fortunehunter. Yet it is Sir Archy who reveals himself to be unworthy, his claims of good character undermined by his ignorant sneering at the cosmopolitan richness of London, acclaimed by Defoe and Addison half a century before, in favour of an outdated mindset:

Why, madam, in Scotland, aw our nobeelity are sprung frai monarchs, warriors, heroes, and glorious achievements; now, here I' the South, ye are aw sprung frai sugar hogshead, rum, puncheons, woolpacks, iron bars, and tar jackets; in short, ye are a composition of Jews, Turks, and

\footnotetext{
46 Tobias Smollett, The Adventures of Roderick Random, ed. Paul-Gabriel Boucé (Oxford: Oxford University Press, 1999), p. 390. Macklin was targeted in Churchill's The Rosciad (1761) along with Arthur Murphy who was described as 'A pert, prim, prater of the northern race', a Scottish association from which Macklin may wish to have distanced himself.
} 
refugees, and of aw the commercial vagrants of the land and sea - a sort of amphibious breed ye are. ${ }^{47}$

Moreover, Macklin makes explicit connections to the historiographical dispute between O'Conor and Hume/MacPherson:

Sir Archy: Hut, hut, hut, away, mon, hut awaw, ye mo no say that; what the de'el, consider our fameelies i' th' North: why yee of Ireland, sir, are but a colony frai us, an outcast! a mere outcast, and as such yee remain tull this hoor.

Sir Callaghan: I beg your pardon, Sir Archy, that is the Scotch account, which, you know, never speaks truth, because it is always partial; but the Irish history, which must be the best, because it was written by an Irish poet of my own family, one Shemus Thurlough Shannaghan O'Brallaghan, and, he says, in his chapter of genealogy, that the Scots are all Irishmen's bastards. ${ }^{48}$

On the face of it then, it is unsurprising that Paul Goring read this play as 'refocusing the gaze' of the audience from the Irish to the Scots. As he documents, local Caledonian reactions to the play were loud and outraged. ${ }^{49}$ Nonetheless, this representation of Macklin as uncritically advocating a 'good Celt/ bad Celt' binary needs further contextualizing as there is no doubt that Macklin was well versed in Enlightenment thought. Equally, even a cursory perusal of his commonplace book indicates that there was a sustained engagement with intellectual ideas of improvement aligned with the composition of his plays. ${ }^{50}$ Historical texts formed an important part of his

${ }^{47}$ Charles Macklin, Love a la Mode (London, John Bell, 1793), 14-15. Macklin was notoriously protective of his works' copyright; it was published in 1793 for reasons of financial need.

${ }^{48}$ Ibid., 21. Macklin is channeling Charles O'Conor whose first history of Ireland is prefaced rather stridently: 'For the Information of those Readers that are not acquainted with the Antiquities of Ireland; it may be proper to observe them, That by the Word Scots, (so frequently used in the following Work) are meaned the antient Inhabitants of Ireland, or the Milesian Race; not those of modern Scotland, except where the Word is distinctly applied to them: And that Ireland was called Scotia major, or the greater Scotland; as was North-Britain, Scotia minor; this latter Country having been colonized by the Scots of Ireland, and established into a Monarchy by one of their Princes'. Charles O'Conor, Dissertations on the History of Ireland (Dublin: James Hoey, 1753), np.

${ }^{49}$ Paul Goring, “"John Bull, pit, box, and gallery said No!”: Charles Macklin and the Limits of Ethnic Resistance on the Eighteenth-Century Stage', Representations 79:1 (2002), 61-81: 71. See A Scotsman's Remarks on the Farce of Love a la Mode (London: J. Burd, 1760).

50 The sale catalogue for Macklin's library reveals an extraordinary range of texts for a man often mocked for his lack of learning. He owned editions of Montesquieu, Addison, Locke, Hume, Goldsmith, Swift, Burke, and multiple volumes of Rousseau, Voltaire, and Toland, among others. A Catalogue of the Library of the Late Mr. Charles Macklin (London, 1797). His commonplace book, held at the Folger Library, 
intellectual make-up: we can trace this both in his library and in his brief spell running the 'The British Inquisition' (a salon for sociable public instruction) in the mid-1750s where he lectured on Irish and British history. ${ }^{51}$

Macklin's over-the-top stereotyping, as Michael Ragussis has shown, 'invites the audience to reflect on the very conditions of spectatorship and spectacle that engross it' and thus 'detheatricalizes' the figures. ${ }^{52}$ One might then read O'Brallaghan's invocation of his impressively named ancestor (Shemus etc.) as rather tongue-in-cheek on Macklin's part, a gentler satire on the Irish-Scottish debate on national origins and Celtic authenticity and one that speaks an attitude more open to ideas of improvement than is commonly recognized.

O'Brallaghan, after all, does not castigate the Scots throughout, he is equally ready to applaud them when appropriate:

I dare say [Scottish soldiers at the Battle of Quebec] were not idle, for they are tight fellows. Give me your hand, Sir Archy; I assure you, your countrymen are good soldiers - aye, and so are ours too. ${ }^{53}$

This paean to Scottish and Irish bravery is an expression of solidarity that serves to underscore O'Brallaghan's immediately preceding eulogy to the death of General Wolfe. It is a moment in the play that looks to the material and historical truths of the three nations' shared experiences and interests, one that demands that the audience look beyond the highly theatricalized representations of national identity and the hotly tempered historiographical exchanges. The pressures and tensions of the actual war force their way onto the stage to bring a moment of uneasy sobriety that exposes the shallow artifice of stage stereotypes. This is satire as, in Dustin Griffin's terms, a tool for the public display of improvement; moreover, just as he had done with Henry VII, it was a chance for Macklin to demonstrate publically his value to the city. Macklin's shift from historical tragedy to satirizing history marks his own intellectual development and an increasing assurance on his part.

History was not only an important strand in the plot of Love à la Mode. It also features in his later play The Man of the World, initially composed around 1762 during the dying throes of the Bute premiership. In this play, the tyrannical and corrupt Pertinax MacSycophant, the Scottish anti-hero, has disinherited his eldest son for daring to prefer English historians over those of Scotland making clear the narrowness and self-interested nature of his interests. This later play develops many of the ideas of Love à la Mode, with Montgomery, the

contains ample evidence that he read many of these texts and that they informed his drama.

${ }^{51}$ Macklin owned a number of historical texts, notably, Charles O'Conor's Dissertations on the History of Ireland (1766). See his lecture notes on 'Hanoverian Kings' in Folger MS. Y.d.515.

${ }^{52}$ Michael Ragussis, 'Jews and Other "Outlandish Englishmen": Ethnic Performance and the Invention of British Identity under the Georges', Critical Inquiry 26:4 (2000), 773-797: 780.

${ }^{53}$ Love à la Mode, 19. 
eponymous man of the world, representing an idealized political future that rejects the venal parochial politics of his father.

Macklin's satire is dualistic in nature: it critiques the local and immediate in order to gesture towards a progressive future. Macklin's O'Brallaghan not only demonstrates his own civility by refusing to satisfy traditional expectations of the Stage Irishman (he is brave, honourable, and verbally dexterous) but is also able to move beyond the standard Irish-Scottish enmity and look to the future. Charles Knight has argued that satire's mockery of other nations celebrates one's own nation but it simultaneously evaluates the validity of the nationalist claims being made and thus 'calls the project of nationalism into question'. ${ }^{54}$ Macklin not only understood this doubleness, he embraced it as part of his Enlightenment self-fashioning. The Man of the World is scathing in its critique of the corruption of the Bute administration but the Scottish character of Montgomery is a generous gesture by Macklin, one that reaches out to the Celtic other: this is a play written by a very public Irishman with a Scottish hero for an English audience, one that seeks to imagine a political arrangement that accommodates all based on Whiggish ideas of liberty. Macklin's confident deployment of satire enables him to move beyond his 'celebrity' status - built around images and ideas of him as a 'wild Irishman' to become a respectable Enlightened figure in the 1780s and 1790s, captured in John Opie's portrait of him now held at the National Portrait Gallery. ${ }^{55}$

Macklin's success and general popularity in the 1760s and after was matched, if not eclipsed, by other prominent Irish figures in the British capital's public sphere: Edmund Burke, Oliver Goldsmith, Hugh Kelly, and Arthur Murphy are some of the other figures whose merits were remarked widely. We might also note that Johnson's Club, a crucible of English Enlightenment culture, was founded just a year later in 1764 and that fully a third of its original nine members were Irish: Burke, Goldsmith, and Christopher Nugent. Claims of Irish barbarity and incivility became more difficult to sustain in the light of their stature within political and cultural circles, such was the public face of the O'Conor and his network's historiography. ${ }^{56}$ These mid-century figures cleared the way for a new generation of Irish dramatists that shared their predecessors' patriot sentiment but might also be thought of operating with a degree of

\footnotetext{
${ }^{54}$ Charles Knight, The Literature of Satire (Cambridge: Cambridge University Press, 2004), 59.

55 On Macklin's earlier dangerous celebrity, see Emily Anderson, 'Celebrity Shylock', PMLA 126:4 (2011): 935-949. On Macklin as an Enlightenment figure, see David O'Shaughnessy, “Bit by some mad whig': Charles Macklin's Cato', Huntington Library Quarterly 80:4 (2017), forthcoming.

${ }^{56}$ Other historians of note here include John Curry, Sylvester O'Halloran, and Charles Vallancey. See Clare O'Halloran, Golden Ages and Barbarous Nations: Antiquarian Debate and Cultural Politics in Ireland, c.1750-1800 (Cork: Cork University Press and Field Day, 2004), passim.
} 
confidence in the wake of Irish parliamentary independence that demanded new satiric possibilities.

Perhaps the most well known indication that a new imagining of the Stage Irishman was expected by London audiences by the 1770s was Sheridan's Sir Lucius O'Trigger in The Rivals (1775). The reviewer for the Morning Chronicle (18 January 1775) condemned what he saw as the anachronistic satire on the Irish that was 'so far from giving the manners of our brave and worthy neighbours'. ${ }^{57}$ Implicit in this critique is the recognition of the new understanding of the importance of the Irish to British military endeavours, soon to be demonstrated again with the American War of Independence. Sir Brallaghan O'Callaghan and other 'reformed' Stage Irishmen, notably Richard Cumberland's Major O'Flaherty (The West Indian (1771)) had set the stage for an Irishman who was capable, resourceful, and attuned to the demands of shoring up Britain's commercial, cultural and political primacy. The concession made by British audiences was a general acceptance of Irish civility as well as a recognition that loyalty to Britain and Irish patriotism could co-exist. ${ }^{58}$ Such recognition was important in the wake of the Volunteer movement and the associated agitation on trade rights and political autonomy. These factors coalesced to produce a more confident, more purposeful, and more collectively driven Irish cultural diaspora than had previously been the case. In such an environment, satire softened with the battle for cultural supremacy with the Scots largely won - at least on stage - and the case for Irish civility made.

The 1780s were perhaps the high watermark of Irish theatrical authority in eighteenthcentury Britain. Playwrights, patriotic and politicized, were keen to seize the moment and assure their British audiences of the bona fides of their political intentions. Moreover, the advent of the 1782 parliament meant that an environment of confidence pervaded among migrant networks in London. One significant outcome was the foundation of the Benevolent Society of St Patrick, an important a key site for Irish patriot networking and was frequented by a number of important playwrights. ${ }^{59}$

For playwrights like John O'Keeffe, Leonard MacNally, Dennis O'Bryen, and Frederick Pilon, satire became more diffuse, gentler, and less frantic than the spleen of Swift or the indignation of Macklin. We have in these writers a more conciliatory tone appropriate for Irish patriots who had won considerable concessions but were still hungry for more, as issues surrounding Irish trade refused to go away. In John O'Keeffe's The Poor Soldier (1782), for instance, Pat returns home from the American wars to discover his love Norah is being courted by the English officer Fitzroy. When Fitzroy discovers that Pat saved his life at the Battle of Beattie's Ford

\footnotetext{
${ }^{57}$ Much of the ire about the character of Sir Lucius O'Trigger was to do with the poor acting of Lee in the part; however, much of the criticism also focused on the illjudged portrait of the Irishman, subsequently revised by Sheridan for later performances.

${ }^{58}$ See Leonard MacNally's The Claims of Ireland, and the Resolution of the Volunteers Vindicated (1782) for an important statement of this principal.

${ }^{59}$ See Craig Bailey, 'Innovation to Emulation: London's Benevolent Society of St Patrick, 1783-1800', Eighteenth-Century Ireland 27 (2012): 162-84 and David O'Shaughnessy, 'rip'ning buds in Freedom's field': Staging Irish improvement in the 1780s', Journal of Eighteenth-Century Studies 38:4 (2015), 541-554.
} 
(1781), he nobly relinquishes his pursuit of Norah, in a public demonstration of the complementarity of English and Irish honour, now brothers-in-arms. Leonard MacNally followed his attempt to cast the Volunteer movement in the Whig tradition with theatrical productions that displayed his admiration of cultural artefacts that were unabashedly English in Robin Hood, or, Sherwood Forest (1784) and Richard Coeur de Lion (1786). Dennis O'Bryen's A Friend in Need is a Friend Indeed (1783) explored the nature of friendship and its demands in a new commercial reality in a reworking of Goldsmith's The Good Natur'd Man (1768). O'Bryen's play also functioned as a gesture to Foxite Whigs of his political loyalties and seems to have been instrumental in securing his place alongside Fox in the 1780s and 1790s. Frederick Pilon, a very successful playwright of the late 1770 s and early 1780 s developed a reputation for the rapid production of pointed assessments of the political events of the day. ${ }^{60}$ In many of these dramatists' productions, satire is still present but it is gentler and less abrasive, and mitigated by the tendencies of both 'laughing' and sentimental comedy, as well as farce.

The close of the century was shaped by the disruptive force of the French Revolution. Questions of national identity had increased force as the English-French binary became more entrenched through conservative propaganda. Ireland's loyalties came under renewed scrutiny as fears of invasion caused England to peer nervously over its shoulder at its other Catholic neighbour. Stage Irishmen from this period continue to appear but, generally speaking, as more docile creatures and with less interesting characterization. Censorship of the theatre had a part to play in this but Irish playwrights seemed to have been muted, certainly relative to the richness of the preceding decade. ${ }^{61}$ The 1798 Rebellion, the 1803 rising, major disturbances 18061816 in Munster and 1819-1823 in the south and west of Ireland had a seismic effect on Anglo-Irish relations: one recent account suggests that the early nineteenth century in Ireland might be considered a 'single, gigantic, 'theatre of disorder', ${ }^{62}$ Satire of national identity continues as Maria Edgeworth's Castle Rackrent (1800), Thomas Moore's Captain Rock (1824) testify and these novels are specifically linked to the recent disorder. For the theatre, however, there seems to be a change of tone. The tragedies of Richard Lalor Sheil, Charles Maturin, and James Sheridan Knowles, three of the most eminent playwrights of the early nineteenth century, collectively hint that the re-emergence of the tropes relating to Irish national identity of 1641 after 1798 had dampened the satiric spirit considerably and that history was indeed repeating itself as tragedy. ${ }^{63}$

60 'Every writer for the stage, who takes advantage of temporary incidents, and raises a laugh at living folly, deserves commendation and encouragement. No modern dramatist falls under this description more immediately than Mr. Pilon.' Morning Chronicle and London Advertiser (24 April 1779).

${ }^{61}$ John O'Keeffe had a number of plays which were heavily marked up or suppressed outright by the Examiner of Plays including The Grenadier (1789); Jenny's Whim (1794); and Quarter Day (1798).

${ }^{62}$ Thomas Bartlett, Ireland: A History (Cambridge: Cambridge University Press, 2010), 246.

${ }^{63}$ See Claire Connolly, 'Theatre and Nation in Irish Romanticism: the tragic dramas of Charles Robert Maturin and Richard Lalor Sheil', Éire-Ireland 41:3 (2006): 185214. 